\title{
Effect of Jihadist Terrorism on the Link Between Entitativisation and Anti-Muslim Attitudes and Behaviors in Cameroon
}

\author{
Gustave Adolphe Messanga and Sylvestre Nzeuta Lontio
}

\begin{abstract}
Cameroon is facing violent Islamist extremism. The literature reports that there is no link between jihadist terrorism and islamophobia. This study questions this observation by assessing the effect of jihadist terrorism on the link between entitativisation and anti-muslim attitudes and behaviors. First, it proposes that entitativisation of Muslims has weak links with anti-muslim attitudes and behaviors. It then postulates that there is a strong link between these attitudes and behaviors. To test these hypotheses, a survey is conducted among 147 students from the University of Dschang ( 89 men and 58 women). They are non-muslims of Cameroonian nationality, aged between 17 and 52 years. The data collected provide empirical support for the hypotheses of the study. It is concluded that jihadist terrorism has an impact on the link between entitativisation and anti-muslim attitudes and behaviors.
\end{abstract}

Index Term - Entitativisation, islamophobia, Islam, radicalization, djihadist terrorism.

\section{INTRODUCTION}

In humanities and social sciences, islamist extremism and jihadist terrorism are important topics. The fight against these societal phenomena is ensured not only by security policies of de-radicalization, but also by public policies and exposed populations. Among the strategies implemented by politicians, one can cite armed fight and programs based on the principles of demobilization, disarmament and reintegration. They aim at the disengagement of violent radicals and their reintegration into society [1]. Populations, for their part, resort to prejudices and stereotypes, religious discrimination, anti-Muslim attitudes and behaviors or contemporary manifestations of hatred [2]. These attitudes and behaviors are constitutive of the construct of Islamophobia [3], just like armed fight.

This study considers Islamophobia as a contemporary or social strategy to combat violent extremism. It is linked to negative and stereotypical judgments towards extremist Muslims. It finds an important echo in the narrative criminalizing Muslims [4]. This narrative permeates important institutional and media discourses. Thus, it opens the way to prejudices, politicization of Islam (judgments relating to Burkas and Burkinis), intolerance in political decision-making and disproportionate reactions to terrorism [4]. In the same vein, the author reveals that media and public opinion reproduce the ingrained prejudices that exist against Muslims and which, in the current security climate, are

Published on July 14, 2021.

Gustave Adolphe Messanga, Department of Philosophy-PsychologySociology, Faculty of Letters and Social Sciences, University of Dschang, Dschang, Cameroon.

(Corresponding e-mail: messangaadolphe@gmail.com /

adolphe.messanga@univ-dschang.org) growing stronger day by day. This is why more than $60 \%$ of publications in about six major Spanish newspapers concerning Islam or Muslims are islamophobic and the news dealing with Islam and women or the veil were more islamophobic than those dealing with Islam and terrorism . Because of all these observations, one might suggest that the armed fight against jihadist groups would be preceded by a negative portrayal of jihad, its followers and Muslims in general. One can add that because of jihadist-inspired terrorism, anti-jihadists would then imagine their social environment as being extremely dangerous, leading them to place any Muslim in an isolated and stigmatized religious category. This is what the research calls "entitativisation" [5]. In this study, this process is seen not only as a strategy of labeling members of the Islamic sect Boko Haram (malicious individuals) and any benevolent non-radicalized Muslims, but also as a strategy of social distancing from radicalism. In this logic, stereotypes and prejudices appear to be important in the study of religious extremism, because they are produced and shared by individuals, targets of terrorist acts, and not by politicians. In line with this perspective, the present study aims to assess the effect of jihadist terrorism on the link between entitativisation, attitudes and security behaviors of populations against Muslims, some of whom are followers of the violent religious extremism.

\section{LITERATURE REVIEW}

The prediction of certain group phenomena, attitudes, and behaviors can be made from the representations or perceptions that members of a group have of other groups [6]. Research has extensively documented issues related to group homogeneity, judgments and perceptions [7], [8]. This literature provides knowledge on both entitativisation and intergroup representations, two foundations of intergroup relations. Intergroup representations are intergroup cognitions or an organization of cognitive elements about a group or a social category [9]. They are cognitive constructions that are expressed in terms of beliefs based on certain group characteristics. They are used to simplify the social structure and facilitate group judgments and perceptions [9], [11]. They do this through biased or stereotypical judgments about groups. These superficial or superfluous judgments [12] are based on clichés or on mental

Sylvestre Nzeuta Lontio, Department of Philosophy-Psychology-Sociology, Faculty of Letters and Social Sciences, University of Dschang, Dschang, Cameroon 
representations allowing to shorten complex judgments about groups. This is why individuals tend to generalize their judgments and knowledge of an individual to the whole of his or her group. Indeed, this knowledge is associated with the characteristics of the target group (group size, status or ideology) and serves to homogenize the way in which it is perceived. This perception is based on the Principle of Cognitive Economy [13], mental shortcuts [14], even the logics of exclusion [15]. These authors analyze the structure of loosely structured and poorly organized groups called « outsiders ». In Campbell's logic cited by [5], these are in fact entitative groups that are systematically stigmatized by the well-established group called «established» [15]. Contrary to entitative groups assimilated to «outsiders», the members of the well-structured group constantly close ranks against the intrusion of external elements, under the pretext of preserving their self-esteem. Strengthened by its social cohesion which gives it charisma in the eyes of other groups, this group will have no difficulty in gaining acceptance for the rumors and prejudices that it continually disseminates against «outsiders». These preconceptions are constitutive of selffulfilling prophecy, to the extent that rejection effectively makes some of those who suffer from it to conform to the negative image applied to them [15]. These elements confirm the logic of ingroup entitativisation relating to the internalization and acceptance, by the members of an ingroup, of the judgments or perceptions of outgroups («established») towards them. In this vein, these preconceptions (prejudices and stereotypes) towards loosely structured groups contribute to the process of entitativisation.

Entitativisation is a social perception [16]. Indeed, it is an intergroup process relating to the tendency of individuals to perceive the members of an outgroup as more homogeneous, unified, coherent and similar than the members of an ingroup. This perceptual tendency is modulated by knowledge or biased knowledge [5]. Research argues that the most important in entitativisation are its effects in terms of stereotypes, prejudices and discrimination [17]. This process is done on the basis of three criteria : the sharing of a common destiny by the members of the target group ; the resemblance or similarity between them ; and physical proximity [5]. Thus, if the members of a group look alike, are close to each other, are united or have a common destiny, then they will be perceived as more homogeneous and more coherent, and therefore members of an entitative group [17], [19]. It follows that if an individual thinks that the members of a given group are on average not very intelligent and that this group is homogeneous, the probability that this individual judges an isolated member of this group as not very intelligent is very strong [5]. Similarly, the more a group is perceived as entitative, the more it is possible that the behavior of one of its members is generalized to the group as a whole [20].

Intergroup entitativisation is known to impact on the degree of discrimination a group will experience [5]. Thus, the more a group is entitativised, the more it is perceived as a monolithic and predictable entity, and the higher the probability that it is the target of stereotypical judgments and discrimination [20]. Consequently, the stakes for the entitativised groups are obvious. Being often perceived as relatively homogeneous, the likelihood of being discriminated against is higher than for their non-entitativised counterparts. However, we note that this tendency to attribute the same characteristics to members of a group may be linked not only to the status of their group, but also to the reputation of some of their members. From the perspective of this research, can we consider the behavior of radical Islamists or armed jihadist groups as a reason for the entitativisation of Muslims?

Since 2014, the Far North of Cameroon has been the scene of an open conflict between the jihadist group Boko Haram and the State of Cameroon. It is a violent conflict that manifests itself in clashes with security forces and attacks on civilians. Indeed, after the attack on the border locality of Amchidé in April 2012, the terror perpetrated by Boko Haram particularly intensified in the Far North of Cameroon, with diversified operating methods [23]. The literature indicates that out of 565 Boko Haram incursions into Cameroon, including 464 attacks and kidnappings, the army was targeted 71 times, from January 2014 to September 2016 [21]. These attacks consisted of ambushes, attacks on villages and suicide bombings. In addition to kidnappings, the literature lists hostage-taking, rape and torture as other modus operandi of the jihadist group Boko Haram. As an illustration, we can cite the kidnapping of one French and two Italian Catholic priests and a Canadian nun [21], [22]. In the same vein, we note the kidnappings, on July 27, 2014 during the attack on Kolofota, of the wife of Cameroonian Deputy Prime Minister Amadou Ali, members of his family and the mayor of the city of Kolofata. In total, Boko Haram has reportedly abducted more than 1,000 people, mostly women and girls, in around 100 attacks. Some of them were used to carry out suicide bombings and others were raped and forcibly married to members of the group. To defend it self against these attacks, the state of Cameroon has deployed more than 3,000 additional troops to secure the Far North region [23]. The record of the fighting between the two belligerents shows at least 125 dead and more than 200 wounded within the Cameroonian security forces, and at least 1,400 civilians killed [21]. Boko Haram attacked not only Christian areas, but also predominantly Muslim communities. Thus, even if many Christians living in the Far North region were targeted between 2014 and 2015, many mosques were also burned down, imams and Muslim faithful were murdered, in the name of the fight against false Muslims [23].

In addition to these deadly attacks, Islamist extremists of Boko Haram commit abuses that specifically affect the functioning of the national economy. Indeed, the agricultural and pastoral sectors are impacted by the attacks of this jihadist group [24]. In particular, there has been a considerable drop in the number of livestock and in the quantity of agricultural production. The reason is that in the context of current insecurity and threat, peasant populations are unable to freely exercise their daily activities; hence the consequences on the humanitarian, security and socio-economic plans [24], [26]. In addition, these abuses expose children to armed conflict, hinder their schooling and facilitate their recruitment, indoctrination and radicalization [24], [27], [28].

Faced with asymmetric crimes, in which the death of thousands of people corresponds to the death of a single jihadist [22], it is possible that these gruesome events affect the relations between Muslims and non-Muslims. Indeed, while it is not proven that every Muslim is a terrorist, the fact 
remains that every terrorist is a Muslim, or at least a fanatic, a follower of Islam. As a result, some might conclude that every Muslim would be a terrorist. In this logic, in view of the atrocities noted above, it is possible that the terrorist acts of Muslims followers of armed jihad affect the representations of non-Muslims towards Islam, in particular through the entitativisation of the members of this religious group. This is evidenced by the increased acts of discrimination that members of this religious group have suffered in Western countries since the September 11 attacks in the United States of America [29], [31]. As a reminder, entitativisation is associated with greater homogenization and is accentuated by ingroup similarity [32], [17], [33]. Thus, besides the similarity between the members of the group, the interconnections, the proximity, the actions directed towards the same goals and the adhesion of the Muslims to the Islamist ideology can favor their entitativisation. In this logic, they could be perceived as being similar to the followers of jihad, which could expose them to discrimination, prejudice and stereotypes, in the logic according to which, when a prejudice towards a group is negative, the related stereotypical traits are also negative [9]. Concretely, Muslims are held responsible for what is happening in the Middle East and North Africa, especially for the terrorist attacks perpetrated by the jihadist army [34]. Thus, the entitativisation of Muslims appears to be a consequence of jihadist terrorism. It results in an amalgamation between the fight against terrorism and the fight against Muslims.

Due to the abuses of the Islamist group Boko Haram, nonMuslim refugees believe that their cohabitation with Muslims has deteriorated [35]. The reason is that the intersecting violence of Boko Haram and the army threatens their security. As a result, they internalize the religious antagonism that is at the root of their suffering and vulnerability; hence the demonization of Islam and its followers, conducive to the emergence of frustrations in the form of symbols and representations of Islam [36]. This is the inherent denominational divisionist representation in which Muslims are labeled.

In Cameroon, the entitativisation of Muslims appears to be a reality. It would operate through stigma, prejudice and discrimination. Indeed, there are important facts that underlie the entitativisation of Muslims in this country [37]. Concretely, faced with the rise of terrorism by the jihadist group Boko Haram in the Far North region in 2015, members of the Mbororo community (a Muslim minority group) were the object of increased discrimination by the administrative authorities of the North-West region [37]. Wearing religious veils has also reportedly contributed to the process of labeling, prejudice and stereotypical perception of Muslim women. As proof, faced with the repetitive abuses by Boko Haram, some Muslim women who wore veils were insulted, stigmatized and discriminated against in the North-West region, probably due to the fact that wearing the full veil is likely to lead to the assignment of individuals to the category of Muslim extremists [37]. In this vein, security measures restricting religious expressions and customs were taken by the administrative authorities of several regions (Center, East, Far-North and West). Thus, collective prayers and the wearing of veil were prohibited at the Faculty of Medicine and Biomedical Sciences of the University of Yaoundé I [37].
This ban contributes to the stigmatization, prejudice and discrimination of Muslim students, and consequently to their entitativisation, that is to say their assimilation to the followers of the jihadist group Boko Haram [38].

Discrimination against Muslims is constitutive of Islamophobia, understood as the set of prejudices and discriminations suffered by members of the Muslim community or any person believed to be part of it. It is the manifestation of hostility towards Islam. It consists of a systematically negative stereotyping of Muslims, Islam and other divine religions, a widespread rise in intolerance and discrimination against Muslim minorities in non-Islamic countries, especially in the West [39]. It incorporates all offenses against Islam and acts of islamophobia. It manifests itself on the attitudinal and behavioral levels. The attitudinal aspect of Islamophobia refers to prejudices and negative stereotypes vis-à-vis members of the Muslim community. The behavioral aspect refers specifically to malicious acts (discrimination, violence or abuse).

The period after the terrorist attacks of September 11, 2001 had the effect of accentuating islamophobia [29], [22]. Indeed, this tragic event, listed as an act of hyper-terrorism due to the large number of deaths (around 2977), reinforced islamophobic representations [40]. These generate a misinterpretation of Islam and attempts to portray this religion as support for violent extremism. Before September 11, 2001, visible minorities of Arab origin already suffered from discrimination and racism, to which was added another problem : their religious affiliation. In fact, reference [40] notes an undeniable rise in islamophobia, characterized by the intellectual legitimation of this religious discrimination. Concretely, we note that Muslims living in Western countries are daily victims of several forms of discrimination based on their religious affiliation [29]. The figures for islamophobia are at alarming levels [41]. In 2016, for example, around 580 islamophobic acts were reported. In addition to these discriminatory acts, there are political speeches containing stigmatizing words vis-à-vis Muslims, in particular those uttered during the presidential campaign of candidate Donald Trump in the United States, the referendum on Brexit in the United Kingdom and of the Burkini episode in France [41].

In Cameroon, the members of the Muslim community in Bamenda reported that during a roadblock in Sagba (North West Region) on August 12, a Muslim woman named Modestine Yida Mbukwe and her 13-year-old relative, Njag Rashida, were physically abused by a gendarme because they were wearing religious veils. Mbukwe said the gendarme cursed him and tried to forcefully remove his veil. She added that a Catholic nun who passed by with a much longer headscarf was allowed to continue on her way undisturbed. The Muslim lady lodged a complaint in the Bamenda military court on August 13. The case remained pending until the end of the year [37]. In the same vein, we can mention: the refusal of school principals to enroll certain Muslim children due to the fact that Boko Haram uses children to carry out suicide attacks, or the arbitrary arrests of Wahhabi imams in Foumban, of members of the Kanuri community and border populations in the Far North region [38]. These discriminatory acts are seen as a condemnation of Islam and the Muslim community as a whole. In this context, discriminatory discourse is generally a victim discourse, 
often used to reverse the accusation towards those who now embody the image of threat.

This study uses intergroup threat theory to explain and predict attitudes and behaviors against violent extremism [42]. This model is likely to determine the factors underlying the increase in anxiety and prejudice against jihad and its followers. It is based on variables that influence prejudices in all groups [43], and supports the idea that intergroup conflict, distinct statuses, ingroup identification's strength, knowledge of outgroups, as well as the nature of contact between groups, determines whether individuals feel threatened or not. It is the assessment of the threat emanating from outgroups that favors the emergence of hostile attitudes towards them [22]. This is why the role of the feeling of intergroup threat and prejudice is highlighted in conflicts [22]. In connection with the present research, the exposure of non-Muslims to the threat of death caused by violent religious extremism could be the source of their motivation to defend their values or their ideology, in particular by harshly judging and punishing Muslims who do not share them. Thus, the latter are likely to be stigmatized and considered the main source of the lethal threat to non-Muslims [22]. This stigma, which tends to fail to distinguish between extremists and non-extremists, is underpinned by the entitativisation process, as defined above. In this logic, the Muslim community, as a whole, is considered as an aggregate, that is to say a group whose members are perceived as undifferentiated copies of the same category [44].

While the literature on discrimination based on religion is abundant in the European and American contexts, there are, however, few empirical studies that analyze, explain and assess the attitudes and behaviors against violent religious extremism in the Cameroonian context. A notable exception is the work of [22], whose objective was to link the jihadist terrorism of Boko Haram and anti-Muslim attitudes. The results of these researchers reveal that in this country, the terrorist acts perpetrated by the followers of this jihadist group born in Nigeria do not generate attitudes and behaviors constituting islamophobia among the non-Muslim population. They therefore do not go in the same direction as the research carried out in European and American contexts which reveals the rise of islamophobia in the post September 11, 2001 period. Anti-Muslim attitudes and behaviors observed in the Western context are linked to the fact that in the West, islamophobia can be seen as a distinctive feature of society and the individual psyche for several centuries [22]. This means that terrorism did not generate it, it just exacerbated it. Moreover, in the West, this religion appears as one of the consequences of immigration. Indeed, in a country like France, almost all Muslims are immigrants or children of immigrants [22]. It means that in this geographical space, Islam is a novelty.The Islam practiced in Cameroon is not situated in this perspective, since it has a popular character which makes it peaceful and tolerant towards other religious denominations; hence the fact that it does not inspire a particular fear, as it does in the

West [22].

Despite the fact that the work of [22] came to the conclusion that the terrorist acts perpetrated by the jihadists of the Boko Haram group do not generate islamophobic attitudes among the non-Muslim Cameroonian population, questions remain. They are linked to this study itself. Indeed, this research had the specific objective of adapting, to the Cameroonian context, an islamophobia scale designed in an Australian context (Attitude Toward Muslim Australians Scale). As a result, the measure of islamophobia reported by its authors falls within the framework of the predictive validation of this measuring instrument. In other words, this research does not establish a causal link between islamophobia and an antecedent factor, as is the case with entitativisation in the present research. Moreover, the study of these authors analyzes only islamophobic attitudes and not behaviors. However, attitudes and behaviors are distinct constructs that may or may not be related, even if they relate to the same objects. In this logic, can we establish links between entitativisation of Muslims, islamophobic attitudes and behaviors on one hand, and between islamophobic attitudes and behaviors on the other?

Referring to [22], the present study proposes that the absence of islamophobic attitudes does not necessarily translate the absence of islamophobic behaviors, if we consider the results of studies which have tried to establish the link between attitude and behavior [45], [47]. Concretely, we expect that:

1. Unlike the study conducted by [6] which establishes a positive and significant link between entity and attitude change, and in agreement with the literature on the issue of islamophobia in the Cameroonian context [22], this research postulates a weak link between entitativisation of Muslims and anti-Muslim attitudes ;

2. Following the logic of the previous hypothesis, it is postulated that there is a weak link between entitativisation of Muslims and anti-Muslim behaviors ;

3. In accordance with the literature on the link between attitude and behavior, this study postulates that there is a strong link between anti-Muslim attitudes and behaviors.

\section{METHOD}

\section{A. Participants}

One hundred and forty-seven $(\mathrm{N}=147)$ students attending various faculties of the University of Dschang (Cameroon) volunteered to participate in the study ( 89 men and 58 women). They are between 17 and 52 years old $(\mathrm{M}=25.40$ years, $\mathrm{SD}=5.65$ ). They are Cameroonians belonging to religions other than Islam. They were given guarantees of anonymity and confidentiality regarding the use of the information they provided for this study.

\section{B. Measures and Procedure}

This study uses three measurement scales. The first is an adaptation of the Outgroup Perceived Entitativity Scale (ÉEP-Ex, $\alpha=.73$ ) [48], originally designed to assess linguistic intergroup relations. It is a standardized measure comprising ten (10) items, of which five (5) are right-coded and five (5) reverse-coded. Some items have been reformulated, in particular by introducing words such as "Muslim, Islam, Islamic, Boko Haram" and deleting terms such as "Francophone, Anglophone, language". By way of illustration, item 3 proposes that: «Muslims and members of the Islamic sect Boko Haram act in the same direction, pursue the same objectives and all have the same fate, because they 
have a common destiny». The second is the revised version of the Attitude Toward Muslim Australians Scale $(\alpha=.86$ for the present study) adapted to the Cameroonian context [22]. This scale consists of sixteen (16) items, of which seven (7) are right-coded and nine (9) reverse-coded. By way of illustration, item 5 proposes that: «All Muslims are potentially terrorists». The third is the Behavioral Islamophobia Scale $(\alpha=.85)$. It was developed using the existing literature on islamophobic acts [34], [41], [29], Law and Justice research mission 2017 [39]. It consists of nine (9) items, of which three (3) are reverse-coded and six (6) rightcoded. For example, item 4 states that: «For the security of our country, suspected Muslims should be subjected to arrest and anti-terrorist treatment». Participants rate their level of agreement for all items of the three instruments on a 7 points Likert scale, ranging from 1 (Strongly disagree) to 7 (Strongly agree).

\section{RESULTS}

The results of this study are presented in two stages. First, using descriptive statistics tools, the means and standard deviations of the variables are analyzed. Next, the hypotheses of the study are tested through linear measures of association ( $r$ Pearson's correlation coefficient) and a conjoint analysis of linear regression, which verifies the causal link between variables.

TABLE I: AVERAges (M.), StANDARD DEVIATIONS (SD) AND CORRELATION INDEX (R)

\begin{tabular}{|c|c|c|c|c|c|}
\hline & $\alpha$ & $\begin{array}{c}\text { M. } \\
\text { [S.D.] }\end{array}$ & 1 & 2 & 3 \\
\hline 1. Entitativisation & .73 & $\begin{array}{c}39.93 \\
{[09.13]}\end{array}$ & & & \\
\hline $\begin{array}{l}\text { 2. Attitudinal } \\
\text { islamophobia }\end{array}$ & .86 & $\begin{array}{c}51.68 \\
{[15.43]}\end{array}$ & .059 & & \\
\hline $\begin{array}{l}\text { 3. Behavioral } \\
\text { islamophobia }\end{array}$ & .85 & $\begin{array}{c}33.52 \\
{[10.02]}\end{array}$ & .049 & $.942^{* *}$ & \\
\hline $\begin{array}{l}\text { 4. Islamophobic } \\
\text { attitudes and } \\
\text { behaviors }\end{array}$ & .90 & $\begin{array}{c}142.06 \\
{[40.68]}\end{array}$ & .072 & $.984^{* *}$ & $.979^{* *}$ \\
\hline
\end{tabular}

Table I shows that the scales used have good internal consistency indices $\left(\alpha_{1}=.77 ; \alpha_{2}=.86 ; \alpha_{3}=.79\right.$ and $\left.\alpha_{4}=.90\right)$, with positive, very strong and significant correlations between the sub-dimensions of the Islamophobic attitudes/behaviors scale and the global scale $(\mathrm{N}=147, \mathrm{r}=$ $.984^{* *}$ and $\left.\mathrm{r}=.979^{* *}, \mathrm{p}<.001\right)$. Thus, participants entitativise Muslims and Boko Haram, as indicated by the entitativisation score which is above average $(\mathrm{M}=44.21>35$ points on average, S.D. = 10.35). These observations indicate the absence of islamophobic attitudes and behaviors among participants $(\mathrm{M}=51.68<52$ points on average, $\mathrm{S} . \mathrm{D} .=15.43$ and $\mathrm{M}=33.52<35$ points on average, S.D. = 10.02). But when we analyze islamophobia as a whole (the attitude/behavior combination), we observe that participants are overall islamophobic $(\mathrm{M}=142.06>91$, S.D. $=40.68)$. This observation validates the existence of islamophobia in the Cameroonian context.

The results in Table I also attest to the existence of both positive, very weak and insignificant links between entitativisation and islamophobic attitudes on one hand, and between the entitativisation and islamophobic behaviors on the other hand, as respectively predicted by hypotheses 1 and $2(\mathrm{~N}=147, \mathrm{r}=.059, \mathrm{p}>.05 ; \mathrm{N}=147, \mathrm{r}=.049, \mathrm{p}>.05)$. They also show that there is a positive, very strong and significant link between islamophobic attitudes and behaviors in the Cameroonian context $\left(\mathrm{N}=147, \mathrm{r}=.942^{* *}, \mathrm{p}<.001\right)$. These results provide empirical support for the hypotheses tested in this research.

TABLE II: LINEAR REGRESSION MATRIX TESTING THE EFFECTS OF JIHADIST TERRORISM ON THE LINK BETWEEN ENTITATIVISATION, ANTI-

\begin{tabular}{|c|c|c|c|c|c|c|}
\hline & \multirow{2}{*}{ Modèle } & \multicolumn{2}{|c|}{$\begin{array}{l}\text { Unstandardized } \\
\text { coefficients }\end{array}$} & \multirow{2}{*}{$\begin{array}{c}\begin{array}{c}\text { Standardized } \\
\text { coefficients }\end{array} \\
\text { Beta }(\beta)\end{array}$} & \multirow{2}{*}{$\begin{array}{l}\text { t-test } \\
(t)\end{array}$} & \multirow{2}{*}{$\begin{array}{c}p- \\
\text { value }\end{array}$} \\
\hline & & B & $\begin{array}{l}\text { Standard } \\
\text { Error }\end{array}$ & & & \\
\hline \multirow[b]{2}{*}{1} & (Constant) & 37.89 & 2.805 & & 13.50 & .000 \\
\hline & $\begin{array}{c}\text { Attitudinal } \\
\text { islamophobia }\end{array}$ & .038 & .054 & .059 & .709 & .480 \\
\hline 2 & Behavioral & 38.32 & 2.622 & & 14.61 & .000 \\
\hline \multirow{3}{*}{3} & islamophobia & .044 & .075 & .049 & .592 & .555 \\
\hline & Islamophobic & -.461 & 1.050 & & -.440 & .661 \\
\hline & $\begin{array}{c}\text { attitudes and } \\
\text { behaviors }\end{array}$ & .676 & .020 & .942 & 33.59 & .000 \\
\hline
\end{tabular}

The matrix in Table II presents a linear regression analysis. In light of these results, we note the positive links between jihadist terrorism and the variables of the study. Thus, the standardized beta coefficients and the $\mathrm{t}$ values of $\beta$ are positive, low and significant. Concretely, we observe that entitativisation of Muslims determines anti-Muslim attitudes, but not significantly $(\mathrm{N}=147, \beta=.059, \mathrm{t}=.709, \mathrm{p}>.05)$. The same is true for anti-Muslim behaviors $(\mathrm{N}=147, \beta=.049, \mathrm{t}$ $=.592, \mathrm{p}>.05)$. On the other hand, the results show that islamophobic attitudes have positive and significant impact on islamophobic behavior $(\mathrm{N}=147, \beta=.942, \mathrm{t}=33.593, \mathrm{p}<$ $.05)$. These observations support the results presented in Table I. Therefore, they also provide empirical support for Hypothesis 3.

The results of this research are summarized in the model below. It fits into the modeling system generally followed in social psychology studies that apply the logic of causal model putting mediation or moderation/modulation into perspective.

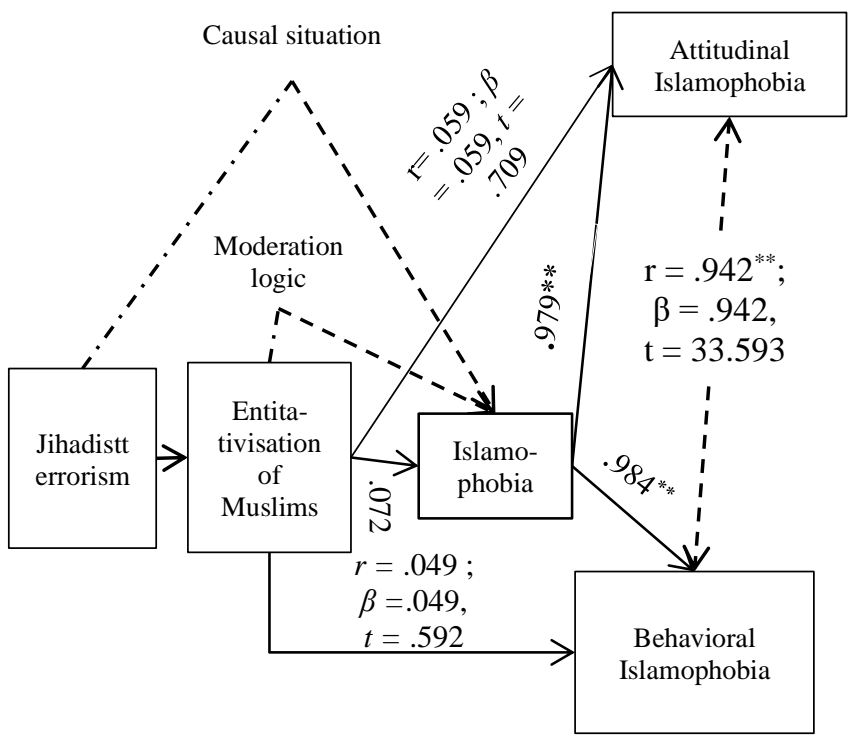

Fig. 1. Modeling of the modulation or moderation of the causal link between jihadist terrorism, entitativisation and islamophobia. Note: The estimation probabilities of the parameters and likelihood indices of the model are $\mathrm{p}<0.05$ for $\beta$ and $\mathrm{t}$, and $\mathrm{p}<.001$ for significant $\mathrm{r}(* *)$ 
Modeling the causal relationship between jihadist terrorism, the entitativisation of Muslims and Islamophobia illustrates the causal pattern and the path explored in this research. Indeed, this model reveals that jihadist terrorism can lead non-Muslims to standardize their perceptions and judgments towards all Muslims without any distinction (entitativisation). This standardization will have an impact on anti-Muslim attitudes and behaviors (islamophobia). The calculated indices appearing in this model make it possible to assess the causal relationships that exist between its constituent elements.

\section{DISCUSSION}

This study assesses the effect of jihadist terrorism on the link between entitativisation, anti-Muslim attitudes and behaviors in Cameroon, with the backdrop of current events on acts perpetrated by jihadists in this country. It tested three hypotheses formulated on the basis of the literature. The data collected provides empirical support for these hypotheses. Thus, there are significant links between islamophobic attitudes and entitativisation of Muslims ; between islamophobic behavior and entitativisation of Muslims ; and between anti-Muslim attitudes and behaviors. We conclude that in the face of jihadist religious extremism, the entitativisation of followers of Islam pushes potential targets of terrorist acts to resort to strategies to combat violent islamist extremism, including the adoption of anti-Muslim attitudes/behaviors. The results of this research are supported by the literature. Indeed, they are similar to the observations made by [22], who come to the conclusion that in the Cameroonian context where people are subjected to the atrocities of Boko Haram jihadists, the absence of antiMuslim attitudes is due to the fact that Muslims are natives of Cameroon and not immigrants. The very weak link between entitativisation and islamophobia points in this direction. Indeed, when islamophobic attitudes and behaviors are analyzed separately, it is observed that the participants do not develop hatred towards Muslims. However, when Islamophobic attitudes and behaviors are taken simultaneously, i.e., in a combinatorial manner, islamophobia is observed. The same is true of the link between entitativisation of Muslims and Islamophobic behavior. Thus, the absence of a causal link between entitativisation of Muslims and attitudinal islamophobia justifies the absence of islamophobic behavior. However, Islamophobia and entitativization resort to stereotypes and prejudices, and can have theoretical links because, according to islamophobes, every terrorist is an Arab or at least a Muslim fanatic [51].

The psychosocial literature that analyzes the link between attitude and behavior [45], [47] helps to explain the results of the third hypothesis. Thus, anti-Muslim attitudes and behaviors are strongly linked. This link is much stronger than the one commonly observed between attitude and behavior in psychology [49]. It is undoubtedly due to the fact that violent religious extremism has created in individuals a certain coherence in the way they think about this phenomenon, the threatening and violent acts relating to it, and the persons who are the perpetrators : Muslims. The latter being identified as the actors of the dangerous and lethal phenomenon that is terrorism, security behavior could consist in being wary of every Muslim, whoever he is, since it is difficult if not impossible to distinguish those among them who are dangerous from those who are not. This is because individuals who are aware that they are mortals produce more intergroup biases [50] constituting, in this case, attitudes and behaviors characteristic of islamophobia.

\section{CONCLUSION}

The results of the present study reveal that entitativisation is a factor determining the inclination for attitudinal and behavioral Islamophobia. By placing oneself in the logic of mediated causal relationships analyzed in social psychology, we can suggest that this quantified factor is a catalyst for Islamophobic attitudes and behaviors. It facilitates the emergence of intergroup religious hatred through stereotyping, intergroup religious preconceptions in terms of prejudice against Muslims and discrimination; hence the tendency of individuals to assimilate all Muslims with their radical co-religionists, responsible for the hatred towards Islam and its followers, especially after terrorist attacks. Therefore, the entitativisation process impacts on the link between jihadist extremism and Islamophobia, by playing a dual role: mediation and moderation. It is therefore a moderating mediator variable in the context of the present research. Specifically, it mediates the effect of jihadist terrorism on attitudinal and behavioral Islamophobia and moderates the link between Islamophobic attitudes and behavior as shown in Fig. 1.

\section{REFERENCES}

[1] O'neill S, Cockayne J (2015) «Conclusion ». In UN DDR in J Cockayne (dir.), S O'neill (éds), an Era of Violent Extremism: Is It Fit for Purpose? Tokyo: UNU-CPR.

[2] Madani I A (2015) Huitième rapport de l'observatoire de l'OIC sur l'islamophobie, Présenté au 42e Conseil des ministres des Affaires étrangères Kuwait, State of Kuwait. https://www.oicoci.org/upload/islamophobia/2015/fr/reports/8th_Ob_Rep_Islamopho bia_Final-FR.pdf.

[3] Manzoni P, Baier D, Haymoz S, Isenhardt A, Kamenowski M, Jacot C (2018) Ampleur des attitudes et comportements extrémistes des jeunes en Suisse. Haute école de travail social Fribourg (HETS-FR). https://www.diaconie.ch/wpcontent/uploads/sites/2/2018/11/Extr\%C3\%A9misme-politique-chezles-jeunes.pdf.

[4] Lurdes VB (2018) Le sectarisme et les politiques de la haine Islamophobie, discours sécuritaires et lutte contre l'extrémisme violent : des liaisons dangereuses. Annuaire Institut européen de la Méditerranée, 68-75. https://www.iemed.org/observatori/areesdanalisi/arxius-

adjunts/anuari/med.2018/fr/Islamophobie_extremisme_violent_Lurde s_Vidal_medyearbook2018_fr.pdf.

[5] Brauer M, Chappe B (2008) Les stéréotypes et la variabilité perçue dans les groupes : état des lieux et enjeux. L'année psychologique 108 (1): 133-167.

[6] Rydell RJ, McConnell AR (2005) Perceptions of Entitativity and Attitude Change. Personality and Social Psychology Bulletin 31(1): 99110. https://journals.sagepub.com/doi/10.1177/0146167204271316.

[7] Schadron G (2005) Déterminabilité sociale et essentialisme psychologique : quand une conception essentialiste renforce la confirmation des attentes stéréotypiques. Les Cahiers Internationaux de Psychologie Sociale 67-68 (3-4) : 77-84. DOI : 10.3917/cips.067.0077.

[8] Schadron G, Morchain P (2003) Nécessité de justifier le sort d'un groupe et perception de son entitativité. Nouvelle Revue de Psychologie Sociale 2(2): 189-200.

[9] Salès-Wuillemin É (2007) Catégorisation et représentations sociales. In M. Bromberg \& A. Trognon (eds.), Cours de psychologie sociale 2: 732. Presses Universitaires de France. 
[10] Lo Monaco G, Delouvée S, Rateau P (2016) Les représentations sociales: Théories, méthodes et applications. Bibliothèque Nationale Paris.

[11] Rateau P, Lo MG (2013) La Théorie des Représentations Sociales : orientations conceptuelles, champs d'applications et méthodes. Revista CES Psicología 6 (1): 1-21.

[12] Keltner D, Gruenfeld D H, Anderson C (2003) Power, Approach, and Inhibition. Psychological Review 110(2): 265-84.

[13] Fiske ST, Taylor S.E (1991) Social Cognition. McGraw Hill.

[14] Racky K (2013) Menace (s) de stéréotype et perception de soi : Comment modérer l'impact des réputations négatives sur les membres des groupes stéréotypés ? Le cas des femmes Noirs de France. Université Paris Descartes. https://tel.archives-ouvertes.fr/tel00838404/document

[15] Elias N, Scotson J L (1998) Logiques de l'exclusion. Notes de lecture NL 003, ISBN : 2-213-59955-6. https://heitzbenoit.files.wordpress.com/2012/04/logiques-de-1exclusion1.pdf.

[16] Scheepers D, Spears R, Doosje B, Manstead ASR (2006) The social functions of ingroup bias : Creating, confirming, or changing socia reality. European Review of Social Psychology 17(1): 359-396. DOI : 10.1080/10463280601088773.

[17] Effron D A, Knowles ÉD (2015) Entitativity and Intergroup Bias : How Belonging to a Cohesive Group Allows People to Express Their Prejudices. Journal of Personality and Social Psychology 108(2): 234 253

[18] Lickel B, Hamilton DL, Wieczorkowska G, Lewis A, Sherman SJ, Uhles AN (2000) Varieties of groups and the perception of group entitativity. Journal of Personality and Social Psychology 78(2): 223246. DOI : 10.1037/0022-3514.78.2.223.

[19] Rothbart M, Park B (2004) The mental representation of social categories : Category boundaries, entitativity, and stereotype change. In V Yzerbyt, C M Judd, O Corneille (eds.), The psychology of group perception: Perceived variability, entitativity, and essentialism 79-100. Psychology Press.

[20] Messanga G A, Ebale Moneze C, Ngueuleu Boukem P (2015) Le syndrome de la reine des abeilles : Evaluation du lien entre entitativité et hostilité à l'égard des membres de l'endogroupe chez les femmes en situation de minorité numérique. Nkà'Lumière 14(2): 119-141.

[21] International Crisis Group (2016) « Cameroun : Faire face à Boko Haram ». Rapport Afrique de Crisis Group N ${ }^{\circ} 241$. Disponible à https://www.crisisgroup.org/africa/central-africa/cameroon/cameroonconfronting-boko-haram.

[22] Messanga G A, Boulla Meva'a AR, Sogbou Loyem S (2017) L'attitude à l'égard des musulmans à l'ère du terrorisme jihadiste : Adaptation d'une échelle de mesure au contexte social camerounais. Cahiers de l'IREA 11: 15-44.

[23] Berghezan G (2016) Boko Haram : Évolution de 2012 à aujourd'hui, fiche documentaire. Note d'Analyse du Groupe de Recherche et d'Information sur la Paix et la sécurité (GRIP), Bruxelles, https://www.grip.org/sites/grip.org/files/NOTES_ANALYSE/2016/N A_2016-01-08_FR_G-BERGHEZAN.pdf.

[24] Wangbe Douga P, Gonne B (2020) Effets de la crise sécuritaire de Boko Haram sur les activités agropastorales dans les Monts Mandara cas de Mora, Extrême-Nord, Cameroun. Frique Science 17(6): 1-17.

[25] Gonne, B. (2014). Effets économiques et sociaux des attaques de Boko Haram dans l'Extrême-nord du Cameroun. Kaliao (volume spécial) 158

[26] Issa S (2014) Les effets socioéconomiques de Boko Haram à l'Extrême-Nord du Cameroun. Revue Kaliao, numéro spécial 142.

[27] CNESS-NIGER (2018) Etude approfondie sur les facteurs de radicalisation en milieu rural, urbain, universitaire et carcéral dans cinq régions du Niger 53- 55.

[28] Owona Ndounda N (2017) Boko Haram et la radicalisation des jeunes au Nord-Cameroun. Entre protestation sociale et nécessité de survie. Émulations: Revue des jeunes chercheuses et chercheurs en sciences sociales. Presses universitaires de Louvain. <hal-01633306>.

[29] Harcourt, B. E. (2006). Is racial profiling an effective counter terrorist measure and does it violate the right to be free from discrimination? http.law.uchicago.edu/Lawecon/index.html.

[30] Kundnani A (2007) The End of Tolerance: Racism in 21st Century Britain. Pluto Press.

[31] Kundnani A (2012) Spot Security Narratives and Far-Right Violence in Europe. Disponible à www.icct.nl.

[32] Crump S A, Sherman S J, Lickel B, Thaklar V (2010) Group entitativity and similarity : Their differing patterns in perceptions of groups. European Journal of Social Psychology 40(7): 1212-1230.

[33] Hamilton D L, Sherman S J, Rodgers J S (2004) Perceiving the groupness of groups : Entitativity, homogeneity, essentialism, and stereotypes. In V Yzerbyt, C M Judd, O Coneille (éds.), The psychology of group perception: Perceived variability, entitativity, and essentialism. Psychology Press 39-60.

[34] Amnesty International (2012) Choix et préjugés: La discrimination à l'égard des musulmans en Europe. Index: Eur 01/001/2012 French, https://www.amnesty.org/fr/documents/EUR01/001/2012/fr/.

[35] Mbarkoutou M H (2014) Réfugiés et personnes déplacées au Cameroun. In I Saïbou (dir.), ISSA Effets economiques et sociaux des attaques de boko haram dans l'extreme-nord du cameroun, (Volume Spécial) 1-156. Université de Maroua, Cameroun.

[36] Pham J P (2012) Boko Haram : la menace évolue. In Bulletin de la sécurité africaine 20. Centre d'Etudes Stratégiques de l'Afrique.

[37] International Religious Freedom Report (2015) « Rapport 2015 sur la Liberté de Religion dans le Monde, Cameroun ». https://photos.state.gov/libraries/cameroon/231771/PDFs/cameroonirf 2015french.pdf.

[38] International Crisis Group (2015) « Cameroun : la menace du radicalisme religieux ». Rapport Afrique de Crisis Group N²29.

[39] Organisation de la Conférence Islamique (2008). Communiqué final de la onzième session de la Conférence islamique au sommet. https://www.oic-oci.org/docdown/?docID=228\&refID=9.

[40] Simonin D (2013) Abdellali Hajjat et Marwan Mohammed. Islamophobie. Comment les élites françaises fabriquent le «problème musulman. Dans Lectures [En ligne], Les comptes rendus, 2013, mis en ligne le 28 novembre. http://journals.openedition.org/lectures/12827.

[41] Collectif Contre l'Islamophobie en France (2017) Rapport annuel sur l'islamophobie en France en 2016. http://www.islamophobie.net.

[42] Mayer N, Michelat G, Tiberj V, Vitale T (2013) La lutte contre le racisme, l'antisémitisme et la xénophobie, Commission nationale consultative des droits de l'homme. La Documentation française. http://www.cncdh.fr/.

[43] Corenblum B, Stephan W G (2001) White fears and native apprehensions : An integrated threat theory approach to intergroup relations. Canadian Journal of Behavioural Sciences 33: 251-268.

[44] Licata L (2007) La théorie de l'identité sociale et la théorie de l'autocatégorisation : le Soi, le groupe et le changement social. Revue électronique de psychologie sociale 1: 19-33.

[45] Ajzen I (1991) The Theory of Planned Behavior. Organizational Behavior and Human Decision Processes 50(1): 79-211.

[46] Ajzen I, Fishbein M (2000) Attitudes and the attitude-behavior relation : Reasoned and automatic processes. In W Stroebe, M Hewstone (éds.), European Review of Social Psychology 11(1): 1-33.

[47] Fay V, Fay N, Walla P (2016) Attitudes of psychology students toward expressive therapies. Cogent Psychology 3(1): 124-145

[48] Messanga G A, Nzeuta Lontio S (2019) Évaluation psychométrique de l'entitativisation dans les relations intergroupes Anglophones/Francophones au Cameroun. Manuscript submitted for publication.

[49] Wicker A W (1969) Attitudes versus Action : The Relationship of Verbal and Overt Behavioral Responses to Attitude Objects. Journal of Social Issues 25: 41-78. https://doi.org/10.1111/j.15404560.1969.tb00619.x.

[50] Boudjemadi V (2009) L'agisme : Étude de la nature, des théories explicatives et des mesures directes et indirectes d'un phénomène psychosocial. Thèse de Doctorat de psychologie, Nancy-Université https://hal.univ-lorraine.fr/tel-01752703/document.

[51] Messanga G A (2019) Mise en évidence expérimentale du recours au profilage ethnique chez les forces de l'ordre dans la lutte contre le terrorisme au Cameroun. Manuscript submitted for publication.

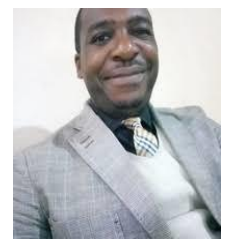

Gustave Adolphe Messanga, (Ph. D), Associate Professor, currently lectures in the Department of Philosophy-Psychology-Sociology, University of Dschang, Dschang, Cameroon. He is interested in Social Psychology of Intergroup relations.

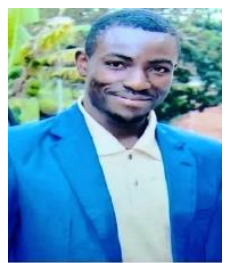

Sylvestre Nzeuta Lontio, MA, Ph. D Candidate, currently student in the Department of PhilosophyPsychology-Sociology, University of Dschang, Dschang, Cameroon. He is interested in Social Psychology of Intergroup relations. 